\title{
PKUbagi Pengurus Ranting Muhammadiyah di Kabupaten Magelang untuk Mengelola Administrasi Ranting
}

\author{
R Arri Widyanto**1, Agus Setiawan ${ }^{2}$ \\ ${ }^{1,2}$ Program Studi Teknik Informatika, Universitas Muhammadiyah Magelang, \\ Jl. Mayjend Bambang Soegeng KM 5 Mertoyudan Magelang, 0293326945 \\ e-mail: *1arri_w@ummgl.ac.id, 2 setiawan@ummgl.ac.id
}

\begin{abstract}
Abstrak
Program PKU ini bermitra dengan Ranting Muhammadiyah Sewukan Kecamatan Dukun dan Ranting Muhammadiyah Tosaren Kecamatan srumbung, yang merupakan jenis mitra kelompok masyarakat non produktif. Permasalahan pada ranting-ranting ini adalah organisasi belum tertata dengan baik, kegiatan administrasinya belum baik, untuk membuat undangan harus ke rental karena pengurus tidak memiliki kemampuan mengoperasikan komputer. Kegiatan ini mempunyai tujuan utuk meningkatkan kemampuan mitra dalam pengelolaan organisasi, meningkatkan kemampuan dalam penyusunan administrasi ranting terutama dalam penyusunan laporan kegiatan ranting muhammadiyah, meningkatkan jumlah pengurus yang memiliki kemampuan menggunakan komputer untuk membantu pembuatan dokumen-dokumen ranting. Kegiatan ini dilaksanakan dengan metode diskusi pemencahan masalah, pelatihan manajemen, penyusunan administrasi, penggunaan komputer, pendampingan dan evaluasi. Pendampingan secara komprehensif kepada pengurus ranting muhammadiyah melalui pendampingan pengeloaan manajemen organisasi, administrasi dan penggunaan komputer untuk membantu kegiatan administrasi. Luaran akhir yang ingin dicapai dari kegiatan ini adalah meningkatnya kemampuan berupa peningkatan pemahaman dan ketrampilan dalam mengelola organisasi dan meningkatkan keterampilan dalam mengoperasikan komputer sebagai alat bantu penyusunan administrasi. Kemampuan mengoperasikan komputer ada peningkatan dari 0,56\% menjadi 0,83\%. Secara ilmiah, luaran akhir dalam kegiatan pengabdian ini adalah terpublikasinya hasil pengabdian ini dalam jurnal ilmiah pengabdian Masyarakat.
\end{abstract}

Kata kunci : Program Kemitraan Universitas, Ranting Muhammadiyah, Administasi

\section{PENDAHULUAN}

Ranting Muhammadiyah, merupakan organisasi dibawah Pimpinan Pusat Muhammadiyah yang secara hirarkhi keorganisasian, merupakan level organisasi paling bawah. Dalam menjalankan organisasinya banyak cabang dan ranting hanya bersifat pasif, hanya menunggu dan menjalankan perintah pimpinan yang di atasnya, dan belum memiliki administrasi yang baik. Hal ini bisa dilihat dari logika garis wewenang. Program PKU ini bermitra dengan Ranting Muhammadiyah Sewukan Kecamatan Dukun dan Ranting 
Muhammadiyah Tosaren Kecamatan srumbung, yang merupakan jenis mitra kelompok masyarakat non produktif.

Ranting Tosaren memiliki anggota dan simpatisan sebanyak 50 orang yang tersebar di dusun Tosaren RT 01-RT 03, Turen RT 01- RT 02 dan beberapa dari dusun Tegalancar dan Goyudan. Demikian juga ranting Sewukan memiliki anggota dan simpatisan sejumlah 20 orang yang tersebar di dusun Suko RT 01-RT 04, Dusun Guwo, Dusun Jengkol, dan Dusun Sewukan 1-3. Kedua ranting tersebut, memiliki potensi dalam pengelolaan zakat, infaq dan sodaqoh yang relatif besar. Demikian juga sudah memiliki kegiatan rutin seperti pengajian selapanan, pertemuan rutin, kajian bulan Ramadhan dan kegiatan rutin yang diselenggarakan cabang dan daerah seperti Silaturahmi Keluarga Besar Muhammadiyah (SKBM).

Permasalahan yang terjadi di ranting, adalah belum ada kegiatan adminsitrasi yang baik, sehingga dokumen-dokumen untuk laporan akhir masa periode pengurus sering tercecer sehingga setiap kali ada kegiatan, tetapi tidak ada laporannya. Selain itu pengelolaan ranting dan administrasinya masih dilakukan secara manual dan dikerjakan ala kadarnya. Misalnya undangan pertemuan ranting masih di foto kopi dan ditulis tangan (gambar 1), belum ada daftar hadir dan notulen rapat, serta untuk pembuatan surat yang akan dikirim ke Cabang atau Ranting yang lain harus menggunakan jasa rental karena pengurus tidak bisa mengetik sendiri. Disamping itu ada juga pengurus ranting merupakan pensiunan pegawai yang tidak terbiasa menggunakan komputer, terutama aplikasi word processor dan aplikasi work sheet. Aplikasi berasal dari kata application (bahasa inggris) yang artinya Penerapan, penggunaan,lamaran. Sedangkan dalam bidangkomputer aplikasi didefinisikan sebagai program siap pakai, program yang dibuat untuk melaksanakan suatu fungsi bagi pengguna untuk aplikasilain. Istilah ini mulai perlahan masuk ke dalam istilah teknologi informasisemenjak tahun 1993 [1]. Aplikasi word processor adalah aplikasi yang digunakan untuk membuat dokumen [2]. Berbeda dengan text editor, aplikasi ini memiliki banyak fasilitas diantaranya mengatur format teks dan fasilitas surat menyurat mail merge. Contoh aplikasinya adalah Microsoft Word. Permasalahan lainnya, pengurus ranting dalam mengelola rantingnya terkesan asal-asalan sehingga organisasi ini hanya terkesan pasif.

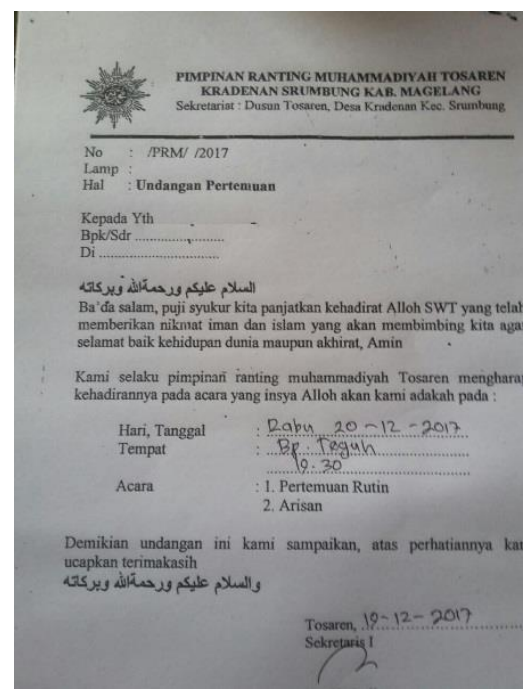

Gambar 1. Undangan Pertemuan Rutin Ranting Tosaren 
Dari ke -2 Ranting tersebut, belum memiliki prosedur administrasi yang baik, belum memiliki pengetahuan tentang administrasi dan keuangan, administrasi ranting belum terdokumentasi dengan baik, sehingga dokumen-dokumen ranting sering tercecer ke manamana dan menyebabkan kesulitan dalam membuat laporan pertanggung jawaban di setiap akhir masa periode jabatan pengurus. Daftar permasalahan dari ke 2 ranting tersebut seperti terlihat pada tabel 1 . berikut.

Tabel 1. Permasalahan Mitra

\begin{tabular}{|c|c|c|}
\hline Nama Ranting & Permasalahan & Solusi yang ditawarkan \\
\hline Ranting Tosaren & $\begin{array}{lr}\text { - } & \text { Kesulitan membuat undangan. } \\
\text { Undangan masih berupa } \\
\text { fotokopian dan ditulis tangan. } \\
\text { - Belum memiliki laporan } \\
\text { keuangan ranting, laporan } \\
\text { keuangan infaq dan shodaqoh, } \\
\text { sehingga sekretaris dan } \\
\text { bendahara hanya membuat } \\
\text { catatan ala kadarnya. } \\
\text { - Rata-rata pengurus belum } \\
\text { memiliki kampuan } \\
\text { mengoperasikan komputer, } \\
\text { sehingga administrasi } \\
\text { dikerjakan secara manual. }\end{array}$ & $\begin{array}{l}\text { Memberikan pelatihan } \\
\text { administrasi surat-menyurat } \\
\text { sederhana, memberikan } \\
\text { pelatihan akuntansi } \\
\text { sederhana untuk membuat } \\
\text { laporan keuangan ranting. }\end{array}$ \\
\hline Ranting Sewukan & 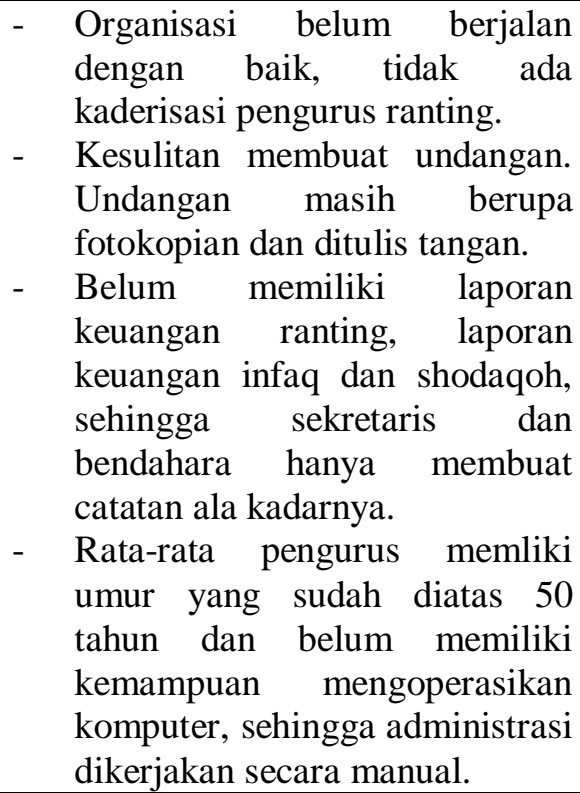 & 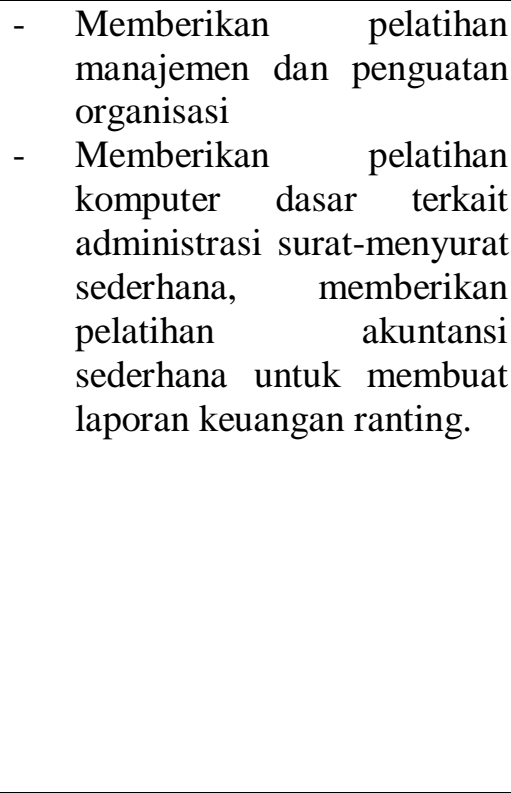 \\
\hline
\end{tabular}

Identifikasi permasalahan yang terdapat pada mitra tersebut, disusun berdasarkan musyawarah tim dengan para pengurus ranting, seperti terlihat pada gambar 2 . 


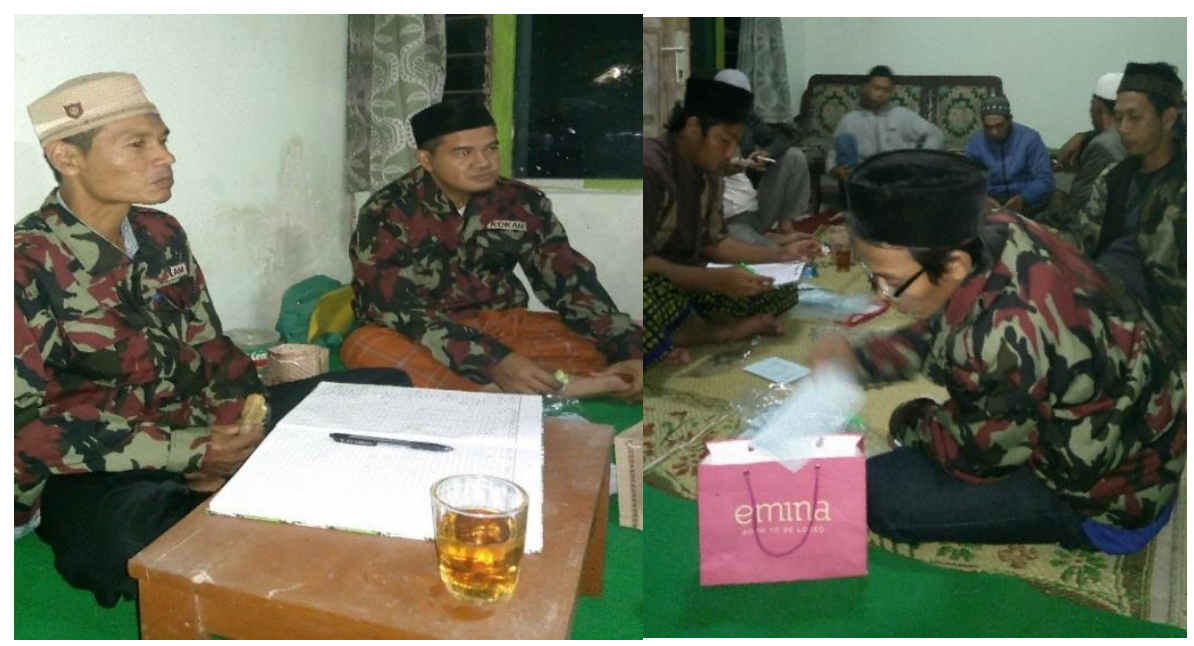

Gambar 2.Pertemuan dengan Pengurus Ranting Muhammadiyah Tosaren

Pengabdian sejenis dilakukan oleh Tri Andari, dkk dengan judul Pemberdayaan Desa Melalui Pelatihan PengoperasianMicrosoft Excel dalam Administrasi DataMatematis Desa. Hasil dari pengabdian ini adalah Para peserta yang mengikuti pelatihan dapat menguasai pengoperasian Microsoft Excel untuk pengolahan administrasi data matematis di desa. Peserta pelatihan termotivasi untuk meningkatkan mutu pelayanan administrasi desa dan proses yang terkait yang dilakukan oleh perangkat desa.[3]Arief, Ulfah Mediaty, Sukamta, Srimelakukan pengadian dengan judul : Pelatihan Komputer Untuk Administrasi Dan Keuangan Pegawai Kelurahan Desa Tegalrejo Kecamatan Tengaran Kabupaten Semarang. Hasil dari kegiatan ini adalah penggunakan Program Microsoft Word dan Microsoft Exell dalam mengolah pekerjaan administrasi dan Keuangan yang ada pada Kelurahan Tegalrejo menghasilkan nilai post-test rata-rata $83.1 \%$ sehingga bisa meningkatkan kinerja pegawai kelurahan Desa Tegalrejo.[4]

\section{METODE}

Kegiatan Pengabdian kepada Masyarakat ini dilaksanakan dalam waktu 3(tiga) bulan terbagi dalam tiga tahap yaitu : tahap persiapan, tahap pelaksanaan,tahap evaluasi dan

penyusunan laporan. Metode yang digunakan dalam bentuk diskusi pemencahan masalah, pelatihan manajemen organisasi, penguatan kelembagaan, penyusunan administrasi, pendampingan dan evaluasi.

Adapun tahapan kegiatan ini meliputi :

a. Tahap Persiapan

1. Koordinasi team Universitas Muhammadiyah dengan masyarakat sasaran, yaitu pengurus ranting, membahas rencana kegiatan untuk penyelesaian permasalahan.

2. Menyusun rumusan tata kelola administasi, menyusun modul-modul pelatihan.

b. Pelatihan Manajemen Organisasi

1. Pelatihan Penguatan Kelembagaan

2. Pelatihan administrasi berupa surat undangan menggunakan mail merge, membuat template administrasi keuangan sederhana dan laporan keuangan.

3. Melakukan pelatihan penggunakan komputer untuk kegiatan administrasi ranting.

4. Pendampingan dalam penerapan teknologi komputer dan manejemen ranting.

c. Tahap Evaluasi

1. Menguji secara praktik untuk mengetahui peningkatan yang terjadi setelah pelatihan.

2. Melakukan diskusi bersama terkait pelaksanaan kegiatan yang sudah dilakukan bersama-sama untuk memberikan tindak lanjut nantinya.

d. Tahap Penyusunan Laporan

1. Membuat Laporan Kegiatan Pengabdian 
2. Penyusunan Draft Jurnal Hasil Pengabdian

\section{HASIL DAN PEMBAHASAN}

Kegiatan ini diawali dengan koordinasi dengan pengurus ranting yang dilaksanakan bersamaan dengan pertemuan rutin ranting tosaren yang dilaksanakan setiap malam Kamis Kliwon. Pertemuan ini dilaksanakan pada hari Rabu tanggal 24 Januari 2018 dari jam 19.30 21.30 membahas pelaksanaan kegiatan pendampingan dan pelatihan komputer. Pelatihan komputer disepakati dilaksanakan dua kali dengan materi Microsod Word dan Microsoft Excel.

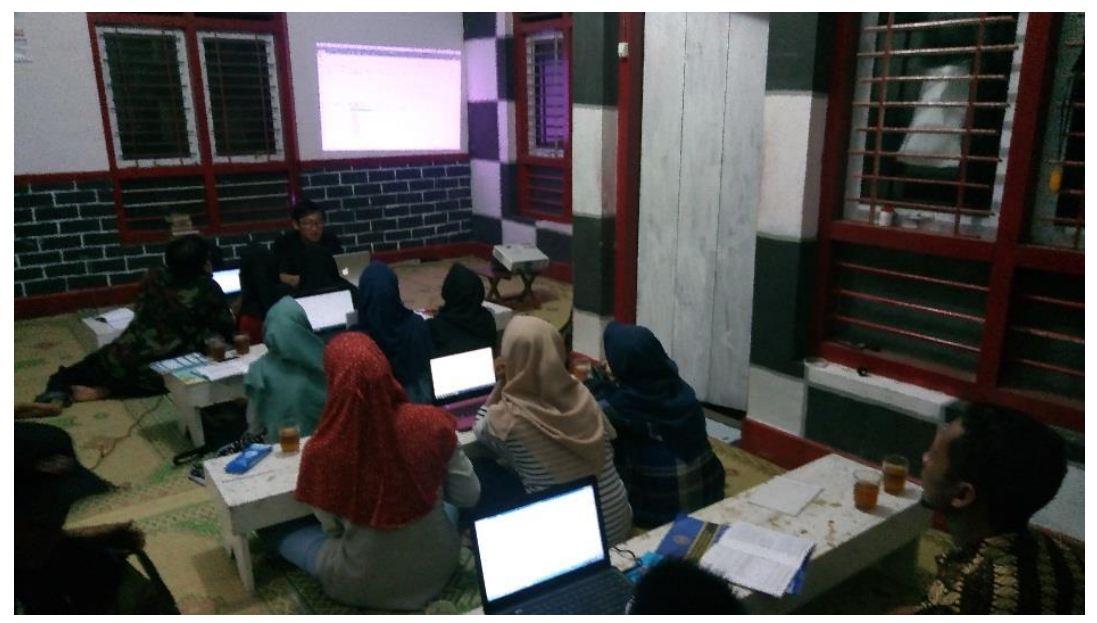

Gambar 3. Kegiatan Pelatihan

Peserta pelatihan yang terdaftar adalah 23 orang. Kegiatan pelatihan dilaksanakan dua kali. Pelaksanaan kegiatan pelatihan yang pertama dilaksanakan di rumah pengurus ranting, materinya pengaturan dokumen, kolom koran, drop cap dan mail merge. Kegiatan dilaksanakan hari Jumat tangga 16 Februari 2018 Jam 19.30-21.30 dihadiri oleh 16 peserta. Pelaksanaan kegiatan pelatihan yang ke dua dihadiri oleh 13 peserta, dilaksanakan di base camp remaja, dengan materi pelatihan adalah microsoft excel berupa fungsi-fungsi seperti $=\mathrm{AVG},=\mathrm{SUM},=\mathrm{AVERAGE}$, dan VLOOKUP. Fungsi adalah suatu procedure untuk mengerjakan fungsi tertentu yang telah disediakan dan kita tinggal menggunakan saja [5]. Fungsi-fungsi ini digunakan untuk mengelola keuangan. Pelatihan ini semula ditujukan kepada seluruh pengurus ranting, sesuai dengan koordinasi awal, tetapi dalam pelaksnaan pengurus ranting mewakilkan Pemuda Muhammadiyah dan Nasyiatul Aisyiyah.

Pelaksanaan kegiatan pelatihan dilaksanakan dengan suatu alternatif solusi melalui pendekatan individual dan klasikal. Pendekatan klasikal dilaksanakan pada saat pemberian dan penyampaian materi mengenai pengetahuan umum komputer dan aplikasinya. Sedangkan pendekatan individual dilakukan pada saat latihan dan tanya-jawab [6].

Kegiatan berikutnya, berupa pendampingan yang dilaksanakan dua kali, yaitu tanggal 28 Februari 2018 dan 10 Maret 2018. Rencana semula pendampingan akan dilaksanakan juga pada tanggal 20 Februari 2018 tetapi tidak terlaksanan, karena terjadi mis komunikasi tim dengan masyarakat sasaran.

Hasil dari kegiatan ini, berupa surat undangan pertemuan rutin ranting yang memanfaatkan mailmerge seperti terlihat pada gambar 3 berikut ini. 


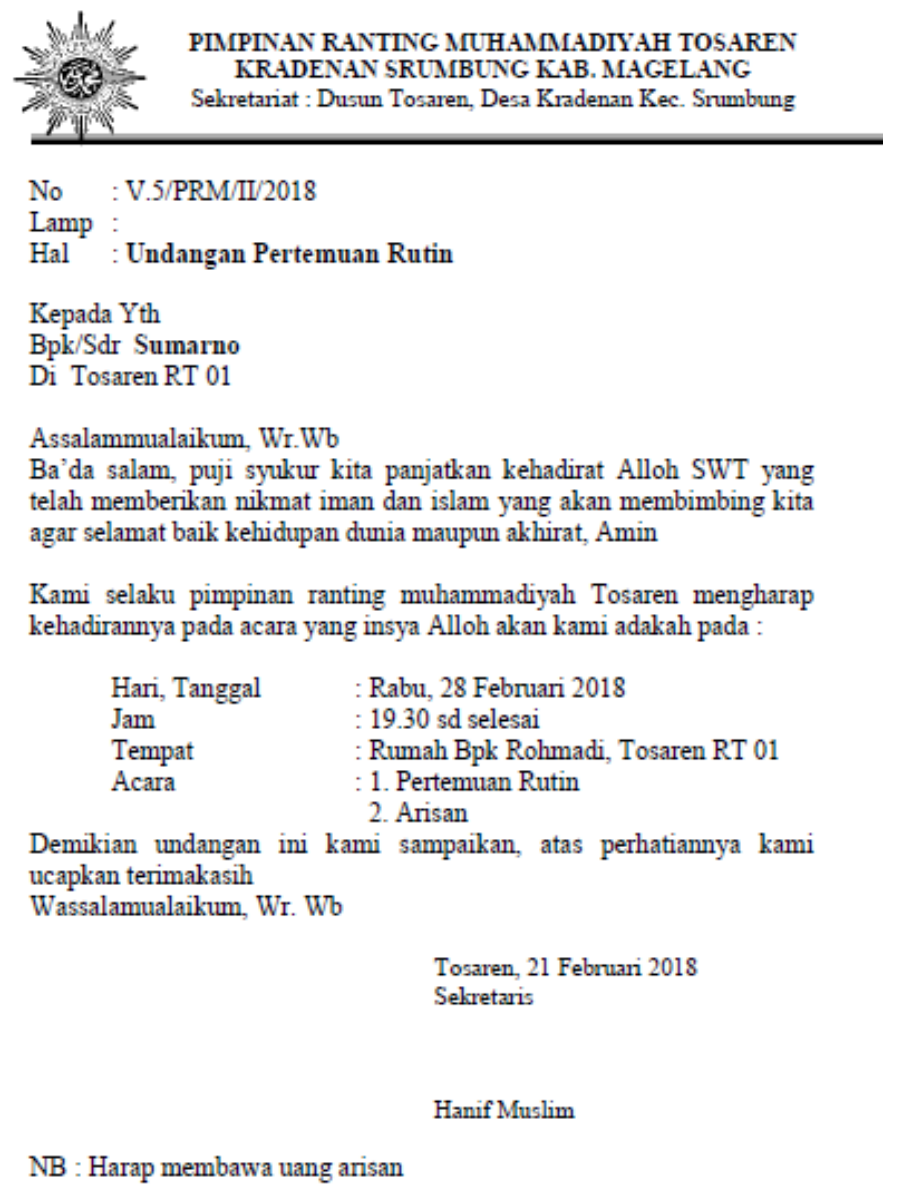

Gambar 4. Surat undangan hasil pelatihan

Pelatihan di ranting Sewukan tidak terlaksana, dikarenakan ada kendala sumber daya di ranting Sewukan yang terbatas. Saat pertemuan awal mengharapkan ada pelatihan, tetapi saat akan dilaksanakan terkendala pengurus ranting yang rata-rata sudah berusia lanjut dan terkendala waktu pelaksanaan, sehingga tidak jadi dilaksanakan. berikut :

Hasil evaluasi pelaksanaan kegiatan pelatihan yang dilaksanakan adalah sebagai

Tabel 2. Hasil Pretest

\begin{tabular}{|l|r|r|}
\hline Rata-rata Nilai & Jumlah Peserta & \multicolumn{1}{|c|}{} \\
\hline A & 1 & $\mathbf{1 , 0 4}$ \\
\hline B & $\mathbf{1 2}$ & $\mathbf{0 , 5 2}$ \\
\hline C & 10 & $\mathbf{0 , 4 4}$ \\
\hline Total & 23 & $\mathbf{1 , 0 0}$ \\
\hline
\end{tabular}

Hasil pretest tersebut peserta yang sudah mahir menggunakan komputer sejumlah 13 orang dari 23 Peserta, atau $0,56 \%$. Sedangkan yang 10 orang belum menguasai atau sejumlah 0,44 $\%$. Setelah dilakukan pelatihan, hasil postestnya terlihat pada tabel 4.2. berikut : 
Tabel 3. Hasil Posttest

\begin{tabular}{|l|r|r|}
\hline Rata-rata Nilai & Jumlah Peserta & \multicolumn{2}{|c|}{} \\
\hline A & $\mathbf{8}$ & $\mathbf{0 , 3 5}$ \\
\hline B & 11 & $\mathbf{0 , 4 8}$ \\
\hline C & 4 & $\mathbf{0 , 1 7}$ \\
\hline Total & 23 & $\mathbf{1 , 0 0}$ \\
\hline
\end{tabular}

Hasil posttest tersebut menunjukkan peserta yang mahir menggunakan komputer sejumlah 19 orang dari 23 peserta atau $0,83 \%$. Sehingga ada kenaikan $0,27 \%$ peserta yang mahir menggunakan komputer. Sedangkan masih ada 4 peserta atau $0,17 \%$ peserta yang belum mahir.

\section{KESIMPULAN}

Dari rangkaian kegiatan yang dilaksanakan, dapat disimpulkan bahwa : hasil pelatihanan Microsoft Word dapat diaplikasikan dalam kegiatan administrasi ranting yaitu dalam pembuatan surat undangan yang memanfaatkan fasilitas mailmerge, sehingga penulisan daftar nama undangan tidak perlu ditulis tangan. Selain itu peserta dapat memahami pemanfaatan fungsi-fungsi pada Microsoft Excel yang dapat digunakan untuk pembuatan laporan keuangan ranting. Secara umum, kegiatan kemitraan ini dapat dirasakan manfaatnya oleh Ranting Tosaren. Kendala yang terjadi tidak semua pengurus bisa berpartisipasi dalam program pelatihan ini, tetapi digantikan peserta dari Pemuda Muhammadiyah dan Nasyiatul Aisyiyah. Kegiatan di ranting Sewukan tidak terlaksana, dikarenakan terkendala waktu dan sumber daya manusia. Kemungkinan pengembangan selanjutnya adalah program kemitraan dengan Pemuda Muhammadiyah dan Nasyiatul Aisyiyah.

\section{SARAN}

Kegiatan berikutnya perlu dicermati program-program kegiatan yang disepakai untuk dilaksanakan dan perlu dipertegas kesanggupan untuk mengikuti dan melaksanakan program yang sudah direncanakan oleh tim dan mitra.

\section{UCAPAN TERIMA KASIH}

Penulis mengucapkan terima kasih kepada Ketua Ranting Sewukan Kecamatan Dukun dan Ketua Ranting Tosaren Kecamatan Srumbung Kabupaten Magelang. Ketua LP3M Universitas Muhammadiyah Magelang, yang telah memberi dukungan financialterhadap kegiatan PKU ini. Selain itu diucapkan terimakasih juga kepada Dekan Fakultas Teknik dan Ketua Program Studi Teknik Informatika Universitas Muhammadiyah Magelang yang telah memberikan ijin untuk melaksanakan kegiatan ini.

\section{DAFTAR PUSTAKA}

[1]. Febrian,Jack,2002. Kamus Komputer dan Istilah Teknologi Informasi,CV. Informatika, Bandung.

[2]. Kadir, Abdul. (2005). Pengenalan Sistem Informasi, Penerbit Andi. Yogyakarta. 
[3]. Andari, Tri , Lusiana, Restu, 2018, Pemberdayaan Desa Melalui Pelatihan Pengoperasian Microsoft Excel dalam Administrasi Data Matematis Desa,Jurnal Terapan AbdimasVol. 1 No. 1 Januari 2016, 29-31.http://ejournal.unipma.ac.id/index.php/JTA/article/view/338

[4]. Arief, Ulfah Mediaty, Sukamta,2018, Pelatihan Komputer Untuk Administrasi Dan Keuangan Pegawai Kelurahan Desa Tegalrejo Kecamatan Tengaran Kabupaten Semarang.Jurnal Abdimas PHB Vol 1 No 1 Januari 2018, 62-66, http://ejournal.poltektegal.ac.id/index.php/abdimas/article/view/705

[5]. Sutanta, Edhy,2005. Pengenalan Teknologi Informasi, Penerbit Graha Ilmu, Yogyakarta.

[6]. Sulistyanto, Hernawan. (2017). Pakom Pelatihan Pengoperasian Komputer Bagi Perangkat Desa Di Kecamatan Gondangrejo Kabupaten Karanganyar, WARTA LPM, Vol. 20, No. 2, September 2017: 111-114, http://journals.ums.ac.id/index.php/warta/article/view/4757 